\title{
A máxima poesia mínima
}

\author{
Adão de Araújo
}

Paulo Leminski, em singelo metapoema, disse:

\author{
Um pouco de mao \\ em todo poema que ensina \\ quanto menor \\ mais do tamanho da china.
}

Nada mais apropriado para o mestre do verso curto, que repetia em língua lusitana o que já dissera o Bardo

e de Avon: "Brevity is the soul of wit". O mesmo fio condutor, que vê nos rebuscamentos vocabulares e excessos estilísticos elementos periféricos da poesia, orientou o percurso da obra de Helena Kolody, ainda que nessa busca de síntese nossa mestra não tenha chegado aos extremos do nosso bom sacerdote paranaense, cujo primeiro nome parece confirmar-lhe a característica preconizada pelo mestre britânico: "A concisão é a alma da sabedoria".

Mas com a poetisa maior do Paraná, à medida que seus cabelos se tingiam de luar, os poemas antigos eram revisitados e sua poesia se tingia de simplicidade. Abandonava ela a camisa de força do soneto e a grandiloqüência castriana de Poetas Mortos, características, aliás, a que nunca se entregara totalmente. Assim, a solenidade do "fulvo oceano de luz" e a tonitruante e caudalosa voz que denuncia os "monstros de pesadelo apocalíptico" dão lugar à comovente simplicidade do menino que recupera a alegria ao contemplar o arco-íris no céu. O quase lamuriante sentimentalismo de Reminiscência cede vez às singelas sinestesias do haicai, cuja semente, já plantada no longínquo 1941, na núbil Pereira em Flor, viria a florescer com todo o viço décadas mais tarde. À guisa de exemplo, o poema "O Inefável", nos quase 50 anos que medeiam a sua primeira publicação e a de 1988, dos 21 versos originais, foi reduzido a 3 , os 3 primeiros. O esforço de dizer o indizível, na vã luta com as palavras, no dizer de Drummond, paradigma de nossa poetisa, se rende ao inevitável paradoxo da im(possibilidade) de expressão.

O poeta é um cosmonauta que encontra na palavra a solidariedade para a sua solidão e que nela consegue refugiar-se da perplexidade ante um universo estupefaciente, cujo controle, escapando-lhe às mãos, não Ihe escapa à onipotência do Verbo Criador. Há a serena percepção de que a existência, outrora "uma jornada, onde se pode encontrar, nalguma curva da estrada, a figura de Lohengrin ou de Jasão", a despeito de suas exigências pragmáticas, não exclui a concretude dos sonhos, a condição mesma da vida, na imbricação da vida biológica e vida existencial, como se constata em

\section{Carência}

\author{
Algo que falta \\ puxa as raízes, \\ sobe no caule, \\ rebenta em flores, \\ no intenso impulso \\ de ir mais além. \\ Vida é carência.
}

Helena Kolody requer, acima de tudo, o exercício da apreensão intuitiva em determinados momentos; em outros, estarrece-nos com o simplismo do óbvio. A vaguidade, que no dizer de Augusto Meyer é a própria essência poética, restitui a possiblidade de auto-sedução, como um etéreo perfume de origem imprecisa. Como um arqueiro zen, com suas flechas-palavras, ela mira a si mesma, e leva a participar 
da visão de que, na percepção do devir, por ser antena da raça (como dizia Ezra Pound), o poeta inventa-se em palavras, conforma-se no dizer. Mais que nunca, o leitor é co-autor, e no momento mesmo da fruição é que se constitui o:

\title{
Significado
}

\author{
No poema \\ e nas nuvens, \\ cada qual descobre \\ o que deseja ver.
}

O fazer poético se configura, acima de tudo, como um espelho que, por reflexo, permite estabelecer a esfera de atuação da consciência. Como recurso de sofismável catarse, leva à constatação de que, nas insondáveis profundezas interiores, encontra-se a matéria-prima que plasma o indizível, a essência destituída de fundo e forma. A palavra é quase pretexto. A deliberada intencionalidade se dilui no fluir de um texto cujo objeto sempre oferece resistência.O signo verbal é mais um obstáculo que um instrumento, mais a pedra bruta que o cinzel. Daí a obsessão pela palavra, pela reflexão sobre o próprio fazer poético, pela verificação dos limites que a palavra impõe. São mais de sessenta metapoemas, o que traduz a incansável busca de significar o poético pela poetização do significado.

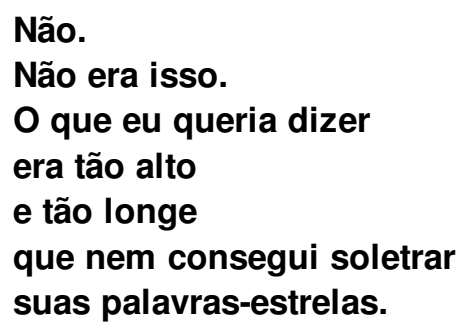

O anelo de transcendência se corporifica na "trans-significação" do inefável, que pulveriza a brevidade da vida e propicia a serena visão da perenidade do ser. A oscilação entre o anseio de Eros e a tirânica inexorabilidade de Tanatos e esfacela, no isomorfismo do Feiticeiro Inventor que não vai aos extremos de um anacrônico pós-romantismo nem desce ao frio gume da precisão matemática de um parnasianismo tardio, mas que, alheio às correntes e contracorrentes de escolas (cujo determinismo categorizante às vezes cumpre função mais descritiva que de penetração na gênese do fenômeno literário), coaduna-se mais a um Neo-Simbolismo, não tanto pelo tratamento dado aos temas quanto pela sua seleção. Não há o intimorato e etílico mergulho nas profundas regiões do inconsciente, pois HK é ela mesma a corporificação dos páramos líricos, como um ser etéreo que nunca desceu completamente à terra. $O$ evasionismo dos primeiros anos foi dandolugar à apreensão do transcendente nas coisas simples do cotidiano, à presentificação das realizações sinestésicas. A persistência da memória propicia alargar (e ao mesmo tempo dissolver...) a dicotomização eu x mundo, e o poeta percebe que existe no mundo que nele existe. O passado não mais a contempla com olhos que já foram seus, e o ontem agora se torna o eterno agora:

\section{Depois}

Será sempre agora.

Viajarei pelas galáxias universo afora. 